\author{
Magdalena Barbaruk \\ ORCID: 0000-0001-6406-2241 \\ Uniwersytet Wrocławski
}

\title{
Misja uniwersytetu. Walka o reformę na Universidad Católica de Chile
}

Abstrakt: Autorka pyta o misję uniwersytetu rozumianego jako aksjologicznie określony sposób życia. Śledzi historię reformy uniwersyteckiej w Chile w XX wieku, jej dwa kluczowe z punktu widzenia refleksji nad uniwersytetem momenty — strajki w latach 1949 i 1967. Zauważa, że fenomen strajku, choć sprzeczny z ideą uniwersytetu, jest narzędziem ujawniania się wspólnoty uniwersyteckiej. Oba strajki miały miejsce na studiach architektonicznych w prywatnym Universidad Católica (kolejno w Santiago i Valparaíso), dlatego też postulaty całkowitej reorganizacji, autonomii badań, modernizacji i demokratyzacji można traktować jako radykalne. Autorka opisuje praktykę badawczą i dydaktyczną tak zwanej szkoły z Valparaíso, która może być uważana za najważniejsze źródło i największego beneficjenta (przyznanie terenów Miasta Otwartego) reformy uniwersyteckiej w Chile. Idee architekta Alberto Cruza Covarrubiasa i poety Godofreda Iommiego Mariniego są też dobrym przypadkiem do analizy problemu autonomii uniwersytetu (zagadnienie apolityczności) oraz skłaniają do stawiania pytań o to, kiedy uniwersytet ponosi klęskę w swojej misji.

Słowa-klucze: uniwersytet, wartości, reforma, strajk, Universidad Católica de Valparaíso (UCV), reforma uniwersytecka 1967, szkoła z Valparaíso, Alberto Cruz Covarrubias, Godofredo Iommi Marini

Kulturoznawcza refleksja nad misją uniwersytetu wydaje się stosunkowo łatwa, gdyż trudno o chętniej wykładaną aksjologię niż tej instytucji. O tym, że uniwersytet jest przede wszystkim miejscem kultywacji wartości, wspólnoty tworzonej przez wybór określonego sposobu życia, przypomniała w Polsce burzliwa dyskusja o tak zwanej ustawie 2.0 (a dokładnie sprzeciw wobec niej zdecydowanej większości środowiska akademickiego). Sprowokowała mnie ona do analizy historii reformy uniwersyteckiej w Chile w XX wieku, zwłaszcza zaś jej dwóch kluczowych z punktu widzenia refleksji nad uniwersytetem momentów - strajków w latach 1949 i 1967. Fenomen strajku, choć sprzeczny z ideą uniwersytetu

* Tekst został przygotowany w ramach otrzymanego z Narodowego Centrum Nauki grantu badawczego pod tytułem „Trajektorie słowa. Kulturowe oddziaływanie Amereidy” (nr 2017/25/B/ HS2/00453). 
(o czym w dalszej części artykułu), jest moim zdaniem wyjątkowo dobrym narzędziem ujawniania się wspólnoty uniwersyteckiej. Oba strajki miały miejsce na studiach architektonicznych w prywatnym Universidad Católica (kolejno w Santiago i Valparaíso), dlatego też postulaty całkowitej reorganizacji wybrzmiewały jeszcze bardziej radykalnie, a przez konieczność wypowiedzenia posłuszeństwa zwierzchnikom kościelnym - odważnie ${ }^{1}$. Za analizą chilijskiego przypadku stały ogólne pytania, między innymi o to, czy misyjność uniwersytetu oznacza wąski i stały zakres aksjologicznych odniesień? Czy refleksja nad uniwersytetem musi mieć normatywny charakter?

Punktem odniesienia dla pytań zadawanych w niniejszym tekście było studium O idei uniwersytetu Władysława Stróżewskiego (nie oznacza to jednak, że utożsamiam się z poglądami tego filozofa). Badacz ten chciał bowiem przypomnieć „czystą, wydestylowaną przez historię ideę" ${ }^{2}$. W konkluzjach pisał jednak o dzisiejszym powołaniu uniwersytetu — o skierowanym ,do nas - ludzi uniwersytetu” wezwaniu: „Wróćmy do universitas rozumianej jako społeczność i zauważmy, jakie bogactwo możemy w niej odnaleźć”3. „Na uczestnictwie w królestwie wartości, ale też tylko na tym, polegać może wychowawcza rola uniwersytetu"4. Kluczowe jest tu zagadnienie, czego w istocie bronimy, walcząc o uniwersytet. Odpowiedzi, które uzyskamy, choć zbliżone do siebie, będą znamiennie się różnić. Pytanie Po co uniwersytet? zadawał już w 1994 roku Leszek Kołakowski, lękając się postmodernistycznego zniszczenia fundamentów wiedzy 5 . Obrona uniwersytetu stanowiła dla niego sposób ochrony człowieczeństwa. Dziś - w obliczu świadomości trudności ze wskazywaniem na to, co odróżnia nas od zwierząt (prymatów) - może zdumiewać pewność, z jaką Kołakowski połączył zasadę istnienia uniwersytetu ze swoistością gatunkową człowieka:

Uczeni mówią nam od dawna, że gatunek ludzki tym się, między innymi, wyróżnia wśród innych, że ludzie w ciągu całego życia przechowują zdolność do bezinteresownej eksploracji otoczenia, bez względu na doraźne potrzeby lub zagrożenia. Uniwersytet jest niejako zinstytucjonalizowaną formą tej właśnie swoiście ludzkiej cechy biologicznej — ciekawości jako samoistnego popędu, zdolności poznawania świata dla samego poznania ${ }^{6}$.

Misja uniwersytetu pod koniec XX wieku mogła być ograniczana do zaspokojenia potrzeb poznawczych człowieka, gdyż wymagał tego zagrożony status

${ }^{1}$ Uniwersytet katolicki, zwłaszcza w randze pontyfikalnego, podlega papieżowi i jako organ Kościoła jest częścią jego świętego życia — vidadivina.

${ }^{2}$ W. Stróżewski, W kręgu wartości, Kraków 1991, s. 7.

${ }^{3}$ Ibidem, s. 24.

${ }^{4}$ Ibidem.

${ }^{5}$ Kołakowski piętnuje w artykule niebezpieczną modę na political corectness, osłabianie poznawczego statusu wiedzy, mówi o powrocie do barbarzyństwa. Gdy brakuje wiary w sens kultury, która powołała i ,przechowała” uniwersytet, staje się on niepotrzebny. Misją uniwersytetu jest stanie na straży tradycji, ciągłości kultury. Zob. idem, Po co uniwersytet?, „Gazeta Wyborcza” 14.03.1994, s. 10-11.

${ }^{6}$ Ibidem, s. 10. 
wiedzy. Dziś ta „funkcja” uniwersytetu musi walczyć o palmę pierwszeństwa z powinnościami krytycznymi, publicznymi. Cezurę w pojmowaniu misji uniwersytetu w Polsce może wyznaczać 2010 rok, kiedy „Krytyka Polityczna” wydała zbiór rozmów i artykułów pod tytułem Uniwersytet zaangażowany. W czasie walki o utrzymanie autonomii uniwersytetu względem regulacji politycznych (dla kulturoznawstwa i wielu innych dyscyplin, zwłaszcza humanistycznych, oznaczających walkę o zachowanie statusu dyscyplinowego) potrzebna okazała się nowa idea uniwersytetu ${ }^{7}$, ,przepisująca” starożytny ideał poznania zgodnie z aktualną akademicką samowiedzą.

Nie ma wątpliwości, że kulturowy sens istnienia uniwersytetu nie może być określany abstrakcyjnie, filozoficznie, lecz musi być rozpatrywany w kontekście historycznym i geograficznym. Nie powinno się zapominać o jego starożytnych antecedencjach, nowoczesnym etapie jego historii, a także o tym, co pozwala odróżnić uniwersytet od innych miejsc, w których zdobywa się wiedzę. Przede wszystkim zaś trzeba pamiętać o tym, że uniwersytet ma nie tyle ogólnoludzki, jak w ujęciu Kołakowskiego, ile europejski charakter. Podkreślał to Ortega y Gasset, utożsamiając Europę z inteligencją:

Bez nauki nie można sobie wyobrazić przeznaczenia Europejczyka. Europejczyk w bezkresnej panoramie historii wyróżniał się jako jednostka prowadząca swoje życie podług swego intelektu, a nauka nie jest przecież niczym innym jak tylko intelektem zawartym „w formie”. Czy to przypadek sprawił, że pomiędzy tak wieloma ludami jedynie Europa posiadała uniwersytety? Uniwersytet jest więc intelektem, jest nauką, jest wreszcie instytucją i właśnie ta instytucjonalizacja intelektu była zamysłem, który odróżniał Europę od innych ras, innych krajów, innych wieków ${ }^{8}$.

Od diagnozy Ortegi y Gasseta łatwo można przejść do wniosku, że obszar, na którym wytwarza się wiedzę naukową, jest niewielki ${ }^{9}$. Na utożsamienie historycznych warunków i normatywnych tez nie pozwalają (oprócz rzeczywistych dokonań uczonych w różnych częściach świata) właśnie wartości. Gdyby było inaczej, mówienie o misji uniwersytetu, nawet nim zacznie się rozważać istotę universitas, byłoby propagowaniem etnocentryzmu i elitaryzmu. O ostatniej niegodziwości pisze sam Ortega: „Uniwersytet reprezentuje przywilej, który trudno jest usprawiedliwić lub obronić" ${ }^{10}$. Pyta też, dlaczego możliwość studiowania

${ }^{7}$ Nawiązuję tu do tekstu T. Majewskiego, Nowa idea uniwersytetu, „Znak” 2018, nr 10 (761). Uniwersytet to my, s. 6-13.

8 J. Ortega y Gasset, Misja uniwersytetu, „Pressje”, przeł. J. Rzegocka, A. Rzegocki, s. 186, https://pressje.pl/media/pressje_shop/article/article_17_issue12.pdf (dostęp: 27.09.2019).

${ }^{9}$ Andrzej Staruszkiewicz pisał w komentarzu do wykładu fizyka teoretycznego Krzysztofa Meissnera: „Wielcy twórcy nauki [...] są jednak produktami określonej kultury. Wystarczy na mapie globu ziemskiego zaznaczyć miejsca ich urodzenia i działalności, żeby zobaczyć, że jest to w skali globu bardzo niewielki obszar” - idem, Komentarz do wyktadu Profesora Meissnera, „Foton” 2010, nr 110, s. 19, http://www.foton.if.uj.edu.pl/documents/12579485/846c3dab-da85-413a-bc2a3720cd6a426b (dostęp: 15.08.2019).

${ }^{10}$ J. Ortega y Gasset, op. cit., s. 182.

Prace Kulturoznawcze 23, 2019, nr 2-3

(C) for this edition by CNS 
mają tylko dzieci z klasy zamożnych, dlaczego nie mogą tego robić wszyscy, którzy powinni: ,jeśli ktoś podobnie do mnie sądzi, że sprawiedliwe jest, aby wiedza uniwersytecka była oferowana robotnikom, to dzieje się tak dlatego, że traktujemy tę wiedzę jako wartościową i godną pożądania" "11. Z tego przekonania zdaniem hiszpańskiego filozofa wynika obowiązek „uniwersalizacji uniwersytetu”. Ten szlachetny postulat brzmi dziś paternalistycznie.

$\mathrm{Z}$ jednej strony mamy więc kłopot ograniczania występowania fenomenu uniwersytetu do Europy, z drugiej zaś pułapkę imperialistycznego przekonania o słuszności krzewienia własnej kultury (gdyż jest „wartościowa i godna pożądania”). Jak traktować zakładanie uniwersytetów w Ameryce Łacińskiej i ich późniejszą dynamiczną historię? Tworzone przez jezuitów placówki edukacyjne odegrały dużą rolę w dziejach tego kontynentu. Czy twórcy misji, w których dokonywano przymusowej ewangelizacji rdzennej ludności w bardziej zakamuflowanej formie, dokonywali podobnej enkulturacji na uniwersytetach? Czy to dlatego w XX wieku dochodziło tam do strajków i aktów wypowiedzenia posłuszeństwa? Czy uniwersytet może być katoli cki? Powinien przecież być wolny od ideologii czy organizacji wyznaniowych. Czy sytuacja uniwersytetu w Ameryce jest zasadniczo inna niż w Europie, gdyż w kontekście nierówności ekonomicznych, społecznych, kulturowych uczeni mają tam inne prawa i obowiązki? Czy z uwagi na kolonialną przeszłość Ameryki oraz doświadczenie dyktatur wojskowych w drugiej połowie XX wieku tamtejsi ludzie uniwersytetu powinni unikać wikłania się w politykę czy też przeciwnie?

Świadoma jestem tego, że europejska refleksja o misji uniwersytetu w Nowym Świecie może być oskarżona o szlachetny paternalizm. Jestem jednak przekonana, że w drugiej połowie XX wieku doszło tam do znamiennych wydarzeń, które powinni znać „ludzie uniwersytetu” choćby dlatego, że w sporach o wizję tej instytucji istotną rolę odegrała refleksja nad relacjami Ameryki i Europy. W artykule przyglądam się interesującej modernizacji wydziałów architektury Universidad Católica de Chile (dziś Pontificia Universidad Católica de Chile, z siedzibami w Santiago i Valparaíso) ${ }^{12}$, który został założony przez arcybiskupa Santiago, Mariano Casanovę, w 1888 roku. W rankingu uniwersytetów Ameryki Łacińskiej (2018/2019) opublikowanym przez QS World University Ranking stołeczny PUC zajmuje pierwsze miejsce, podczas gdy PUCV jest na dwudziestym piątym miejscu ${ }^{13}$.

11 Ibidem, s. 182-183.

12 Dwie siedziby Pontificia Universidad Católica de Chile odróżnia się za pomocą nazw i ich skrótów jako: Pontificia Universidad Católica/PUC (Santiago de Chile) i Pontificia Universidad Católica de Valparaíso/PUCV. W latach walki o reformę uniwersytet w Valparaíso nie miał jeszcze statusu ,pontyfikalnego”, aż do 2003 roku nazywał się zatem Universidad Católica de Valparaíso (w skrócie UCV).

13 Zob. https://www.topuniversities.com/university-rankings/latin-american-university-rankings/2019 (dostęp: 27.09.2019); lub https://en.wikipedia.org/wiki/Rankings_of_universities_in_Latin_America (dostęp: 27.09.2019). 
Warto zauważyć, że w Santiago od 1841 roku istniał już państwowy Universidad de Chile, którego pierwszym rektorem był Andrés Bello, wenezuelski humanista uważany za twórcę nowoczesnego latynoamerykanizmu. Prawdziwie nowoczesną postać uniwersytetowi nadał Ignacy Domeyko, będący jego rektorem aż szesnaście lat (1867-1883), w momencie kluczowym dla tworzenia się zrębów narodu chilijskiego. Geograf wzorował się na Uniwersytecie Wileńskim i — zgodnie $\mathrm{z}$ generalną, światową tendencją — na uczelniach niemieckich ${ }^{14}$. Udało mu się wtedy przekształcić go z organu zarządzającego szkolnictwem elementarnym w placówkę naukową, której słynnymi absolwentami w XX wieku byli: Pablo Neruda, Salvador Allende, Gabriela Mistral czy Michelle Bachelet. To jednak na prywatnym, katolickim, uniwersytecie miały miejsce — począwszy od 1949 roku tak rewolucyjne wydarzenia, jak wypowiedzenie posłuszeństwa zwierzchnikom kościelnym, strajk okupacyjny czy publikacja manifestu opisującego postulaty reformatorów w codziennej gazecie. Czy to dlatego, że w misji tego uniwersytetu wartości, także religijne, są szczególnie obecne?

Stróżewski przyjmuje, że „w strukturę uniwersytetu jest niejako wpisana jego a u t o r e for m ow al n o ść [wyr. - W.S.]"15, reformowanie programów badawczych i dydaktycznych. Powoływanie nowych kierunków badania i nauczania nie jest więc sprzeczne z „ogólnoludzkimi regułami używania intelektu” ${ }^{16}$. Prace nad tak zwaną reformą uniwersytecką w Chile zaczęły się w latach dwudziestych $\mathrm{XX}$ wieku, co było związane z promieniowaniem studenckich strajków z argentyńskiego miasta Córdoba, które wybuchły w 1918 roku (znanych jako grito de Córdoba, czyli „krzyk Córdoby”) i żądały demokratyzacji i nadania uniwersytetowi naukowego charakteru. Droga Chile była jednak osobna. Najważniejszym etapem reformy był okres między rokiem 1967 a 1973, kiedy powstał studencki ruchu protestu, wspierany zarówno przez pracowników naukowych, jak i administracyjnych uczelni ${ }^{17}$. Żądanie protestujących dotyczyło podstawowej misji uniwersytetu, a jednak — jak każdy strajk w tej instytucji — godziło w jego istotę.

14 „Okres między 1831 i 1933 rokiem jest stuleciem bezspornego autorytetu nauki niemieckojęzycznej, w istocie będącej nauką uniwersytecką. Struktura niemieckich uniwersytetów w tym czasie stwarza po temu instytucjonalne przesłanki; jako »Uniwersytet Humboldta« jest w świecie uznawana i naśladowana" - H. Schnädelbach, Filozofia w Niemczech 1831-1933, przeł. K. Krzemieniowa,Warszawa 1992, s. 42.

15 W. Stróżewski, op. cit., s. 12.

${ }^{16}$ L. Kołakowski, op. cit., s. 10.

17 Jeśli chodzi o reformę studiów architektonicznych, to warto wspomnieć o latach 1933 i 1944, kiedy na państwowym Universidad de Chile pojawiły się ruchy studenckie żądające zmian w nauczaniu. Pozostawały one pod wpływem awangardowych idei europejskich, które pojawiły się po I wojnie światowej. W 1933 roku studenci (a wśród nich Juan Borchers) inspirowali się także lokalnym kierunkiem Decembristas (zwanym tak od Wystawy Grudniowej w Santiago de Chile, na której swoje prace zaprezentowali artyści używający stylu abstrakcyjnego) oraz twórczością wielkiego chilijskiego poety Vicente Huidobro. Z kolei ruch studencki z 1944 roku czerpał z autorytetu Tibora Weinera, który kształcił się w Bauhausie i miał wpływ na zmiany w programie nauczania architek- 
Wykładowcy uniwersytetu nie są bowiem zwykłymi pracownikami, są współodpowiedzialni za uczelnię, wchodzą w skład jej ciał kolegialnych. W związku z tym, jak pyta Stróżewski: „Czy można strajkować przeciw sa me mu s obi e [wyr. - W.S.]? W jakim zakresie dopuszczalny jest bojkot zajęć przez studentów — ta forma protestu bowiem wydaje się na uniwersytecie o wiele bardziej naturalna aniżeli strajk?"18.

Historycznym tłem wydarzeń, których kulminacją był napisany przez Godofredo Iommiego Manifest 15 czerwca $1967^{19}$ i zajęcie budynku uniwersytetu w Valparaíso, był strajk studentów Escuela de Arquitectura UC w Santiago w 1949 roku. Był on pierwszym na świecie strajkiem studenckim w historii wszystkich uniwersytetów katolickich. Trwał trzy miesiące, a jego bezpośrednią przyczyną była obrona zajęć z plastyki (Taller de Plástica), jakie na pierwszym roku studiów prowadził architekt Alberto Cruz Covarrubias. Uniwersytet był uczelnią prywatną, przez co mógł to być „strajk przeznaczony na najbardziej absolutną porażkę, czy to z powodu rozpadu grupy strajkującej, czy sankcji uniwersytetu" ${ }^{20}$. Za zorganizowaniem obrony wykładowcy stało Centrum Studentów (Centro de Alumnos), wspierane przez Uniwersyteckie Centrum Akcji Katolickiej (AUC), a ideowy ton strajkowi nadawał wspierany przez młodych wykładowców argentyński poeta Godofredo Iommi.

Choć źródła formułowanych postulatów odnowy uniwersytetu można widzieć w stopniowym reformowaniu się studiów architektonicznych w Chile (zob. przypis 18), to nie bez znaczenia były tu osobiste talenty Alberto Cruza, którego francuski filozof François Fédier, uczeń i thumacz Martina Heideggera, późniejszy współpracownik Cruza i Iommiego, nie wahał się nazwać geniuszem, jednym z kilku, jakich miał okazję poznać w ciągu swojego długiego życia ${ }^{21}$. Cruz skończył studia architektoniczne na Universidad Católica w Santiago, które opierały się na tradycjach zawodowych École des Beaux-Arts, ale sam preferował inny sposób nauczania: „,był znany z niekonwencjonalnego podejścia. Chodził między stołami podczas wykładów, odpowiadając na pytania swoich uczniów: ¿Y tú qué

tury. Zob. F. Pérez Oyarzun, Arquitectura en el Chile del Siglo XX, t. 2. Modernizacion y vanguardia 1930-1950, Santiago de Chile 2016, s. 137-138.

18 W. Stróżewski, op. cit., s. 22.

1915 czerwca był datą symboliczną dla strajku studentów w Córdobie w 1918 roku — wdarli się wtedy do budynku uniwersytetu, by powstrzymać wybór rektora przeciwnego reformie.

${ }^{20}$ L. Rodríguez, La Vanguardia en Chile. Reforma de 1949 en La P.U. Católica, „CA” 1992, nr 69, s. 61; jeśli nie podano inaczej, przeł. M.B.

21 „Alberto Cruz był absolutnie genialną osobą. Mogę powiedzieć, że w swoim życiu miałem przyjemność znać 5 albo 6 genialnych osób. Cruz był jedną z nich. Prawdopodobnie był osobą najbardziej zaskakującą. Gdy mówił, nie mogłeś antycypować następnego słowa. Nigdy! To było absolutnie fascynujące" - zapis rozmowy Magdaleny Barbaruk z François Fédierem, która odbyła się 13 września 2019 roku w Paryżu (w posiadaniu autorki). 
piensas?"22. Wspominając czasy studiów architektonicznych, Mariano Puga Concha $^{23}$ mówi, że na Wydziale Architektury istniał „ruch szalonego Cruza”, „grupa szaleńców" (movimiento del loco Cruz, grupo de los locos) ${ }^{24}$. Cruz kwestionował obowiązujący sposób nauczania architektury, zwłaszcza zajęć praktycznych (talleres), otwarcie krytykował profesorów i dyrektora szkoły, a także budził świadomość studentów, pytając ich nieustępliwie „Co znaczy być architektem dziś?”. Odnosząc się do specjalizacji innych wykładowców, pytał prowokacyjnie, jaką architekturę chcą tworzyć: francuską, epoki Tudorów czy kolonialną? Czy chcą być ,architektami klientów”?

Po powrocie Cruza z Europy, gdzie zetknął się z Bauhausem i ideami Le Corbusiera, setka studentów I roku zaczęła dzielić się na jego zwolenników i przeciwników. Doszło nawet do otwartego konfliktu części studentów z dyrekcją i wykładowcami. Puga wspomina jedno z gorących spotkań podczas trwania strajku w przestrzeni uniwersytetu, gdy José Vial, młody współpracownik Cruza, zapytał rodziców studentów „Dlaczego wysłaliście swoje dzieci na studia architektoniczne?”. Po początkowym oburzeniu i wyjaśnieniach Viala jeden z rodziców odpowiedział: „Chcemy, by nasze dzieci były wybitnymi specjalistami, realizującymi jak najlepiej zamówienia inwestorów"25. Vial miał odpowiedzieć (parafrazując wspomnienie Pugi): „My chcemy dokładnie czegoś przeciwnego. To uniwersytet, który jest powołany do poszukiwania prawdy architektury. Jeśli chcecie spełniać żądania klientów, zabierzcie swoje dzieci" 26 .

22 „¿Y tú qué piensas?” — „A ty co myślisz?”. A.M. Pendleton-Jullian, The Road That is Not a Roadand the Open City, Ritoque, Chile, Cambridge, MA 1996, s. 15.

23 Przypadek Pugi jest interesujący, ponieważ ukazuje rezultaty nauki u „szalonego Cruza”. Puga nie skończył studiów architektonicznych z powodu powołania, jakie poczuł, projektując i realizując wraz z grupą studentów różnych specjalności mieszkania socjalne dla slumsu San Manuel nad rzeką Zanjón de la Aguada (dzielnica San Joaquín, Santiago de Chile). Widok ekstremalnej biedy sprawił, że stał się później „księdzem robotnikiem”, łączącym obowiązki duszpasterza i pracownika budowlanego. W czasie dyktatury był siedmiokrotnie więźniem obozów koncentracyjnych (do Villa Grimaldi i Tres Alamos porywano go w trakcie pracy fizycznej). Z powodu lewicowych poglądów (należał do ruchu Cristianos por Socialismo) i ekstremalnej wierności ewangelii był problematyczny dla sprzyjającego dyktaturze Pinocheta Kościoła i ponosił tego konsekwencje. Zestawienia dwóch życiowych dróg: wrażliwości społecznej i zaangażowania politycznego, które odsunęły Pugę od zawodu architekta, oraz dążenia Cruza do realizacji wizji architektury, które doprowadziło do apolityczności tworzonej przez niego „Szkoły z Valparaíso”, warte jest przemyślenia. Puga podkreślał, że w seminarium znalazło się aż sześciu architektów, „dziedziców radykalności”, którzy chcieli zostać duchownymi-robotnikami, żyjącymi ,jak biedni i z biednymi”. Radykalność, której doświadczyli na uniwersytecie, chcieli przenieść do seminarium i wprowadzić w życie. Puga uważał też, że wszystkie wielkie ruchy ideowe i polityczne narodziły się na uniwersytecie, w związku z czym w seminarium kontakty z uniwersytetem uważano za „zaraźliwe”.

${ }^{24}$ M. Puga Concha, La Quema del Vignola, nagranie z 25 listopada 2014 roku, zrealizowane na Wydziale Architektury Uniwersytetu Katolickiego w Santiago de Chile, https://vimeo.com/113156995 (dostęp: 31.08.2019).

${ }^{25}$ Ibidem.

${ }^{26}$ Ibidem.

Prace Kulturoznawcze 23, 2019, nr 2-3

(C) for this edition by CNS 
Celem strajku w 1949 roku było żądanie wyeliminowania Neoklasycyzmu, symbolizowanego przez obowiązujący w nauczaniu I roku traktat Jacopo Vignoli O pięciu porzadkach w architekturze, i zwrot ku ,architekturze Współczesności”"27. Architekt León Rodríguez mówi, że w strajku uwidocznił się konflikt dwóch wizji architektury, a zarazem dwóch postaw wobec historii i życia, przy czym jedna z nich wynikała z problemów z Kościołem katolickim w Chile. Tamtejsze duchowieństwo bojące się tego co, światowe, historyczne, kontynuowało postanowienia soboru trydenckiego (1545-1563) i soboru watykańskiego (1869-1870). „Przeważała postawa antyprotestancka, antyliberalna, antyidealistyczna, antymodernistyczna, antykomunistyczna, antykapitalistyczna, antymasońska, antyewolucjonistyczna etc.”28. Postawa ,anty” i dążenie do zachowania status quo przez jezuicki rektorat wpływały na konserwatywny model myślenia o architekturze, która miała być naśladowaniem dawnych europejskich historycznych stylów, nie zaś tworzeniem nowych obiektów, a przez to kreacją przestrzeni życia swoistych dla Ameryki Łacińskiej.

Na skutek kilku przemyślnych „taktyk” studentów strajk zakończył się sukce$\mathrm{sem}^{29}$. Odśpiewane w Bazylice Łaski przez władze kościelne, w tym Wielkiego Kanclerza UC i arcybiskupa Santiago, kardynała José María Caro, oraz nuncjusza apostolskiego, Te Deum - podziękowanie Bogu za to, co się wydarzyło - Rodríguez traktuje jako profetyczny znak zapowiadający reformy II soboru watykańskiego (tezę o prekursorstwie ducha reformy na UC wobec Vaticanum II stawia też Mariano Puga). Rektorat przyjął żądania studentów, powołując na dyrektora studiów Sergio Larraína (dziekan i dyrektor szkoły zatrzymali swoje stanowiska, Larraín został dziekanem w 1953 roku). Zatwierdzono profesorów, którzy identyfikowali się jako „współcześni”, i usunięto „akademików” — Miguela Vengasa i Carlosa Casanuevę.

Puga wspomina, że na Te Deum każdy student miał przynieść książkę z architektury klasycznej. Po uroczystości doszło do słynnej sceny — spalenia na dziedzińcu Wydziału Architektury traktatu Vignoli. Przewodniczył temu Larraín, ikona modernistycznej architektury w Chile, autor obiektu Oberpaur (1929), który wzorowany był na domu towarowym Schocken Ericha Mendelsohna w Stuttgarcie (1926). Stos około dwustu książek miał dwa metry. Puga spalił wtedy cenny egzemplarz z XVII wieku, który należał do jego ojca, parlamentarzysty i ambasadora Chile w USA. Choć zwykle palenie książek, także w Ameryce Łacińskiej,

${ }^{27}$ L. Rodríguez, op. cit., s. 61. Autor poprzez wielkie litery Neoklasycyzmu i Współczesności akcentuje zderzenie dwóch nurtów w obrębie studiów architektonicznych.

${ }^{28}$ Ibidem.

${ }^{29}$ Kiedy watykańscy zwierzchnicy UC zabronili „strajku” (hiszp. huelga), studenci zamienili zakazane słowo na coicidencia de ausencia (,zbieżność nieobecności”) — M. Puga Concha, op. cit. 
wiąże się z wprowadzaniem dyktatury, nie był to jedyny przypadek, gdy doszło do przechwycenia gestu $\mathrm{w}$ imieniu przeciwnych zniewoleniu jednostki wartości ${ }^{30}$.

Reforma, która dokonała się na Universidad Católica w 1949 roku, zakończyła tradycyjne nauczanie architektury w Chile. Ten zwrot ku współczesności wymaga jednak zaznaczenia odmienności wizji Larraína oraz Cruza i Iommiego, co miało wpływ na dalsze losy walki o wizję uniwersytetu. W projekcie późniejszych twórców Amereidy ${ }^{31}$ nowoczesność nie była wiązana z pragnieniem wznoszenia obiektów podobnych formalnie do europejskich (jak Oberpaur), lecz z czerpaniem z nowoczesnej poezji. Poezja postrzegana jest tu jako sposób zmiany życia, który jest wyprowadzany z niego samego, przekształca myślenie o przestrzeni, $\mathrm{w}$ jakiej zamieszkuje człowiek, bez jednoczesnego gloryfikowania technologii, masowej produkcji. W związku z tym studia architektoniczne stawały się bliższe kierunkom humanistycznym niż zawodowym. Nowoczesność w architekturze w wizji Cruza była przede wszystkim sposobem życia, czego przykładem było wyprowadzanie studentów architektury z sal wykładowych w celu systematycznego, wnikliwego obserwowania miejskiego życia stolicy ${ }^{32}$. Praktyka ta budziła na ówczesnym uniwersytecie zgorszenie, ale konsolidowanie się wokół Cruza i Iommiego grupy młodych współpracowników — nie przedsiębiorców, technologów i deweloperów, lecz poetów, malarzy, rzeźbiarzy, filozofów — musiała robić wrażenie. Po sukcesie strajku Cruz został zaproszony przez rektora UCV, jezuitę Jorge Gonzáleza Förstera, do Valparaíso, by utworzyć tam własną szkołę architektury. To tam przeniosła się radykalna reforma, przez co studenci architektury

${ }^{30}$ W 1939 roku Iommi i kilku innych poetów tworzących grupę Santa Hermandad de la Orquídea spalili na jednym z placów w Buenos Aires zeszyty z własną poezją. Celem tego rytuału przejścia - zwanym od bliskości baru Victoria, gdzie przesiadywali poeci, Pacto de la Victoria („Pakt Zwycięstwa”) - było uwolnienie poezji z pisma, by mogła być ona realizowana w życiu. Niedługo po tym wydarzeniu grupa zaczęła poetycką wyprawę po Amazonii pod hasłem Dante o nada (,Albo Dante, albo nic").

31 Amereida to stworzony przez Iommiego (zwanego przez jego współpracowników „Godo”) neologizm łączący Eneidę i Amerykę, którym zatytułowano poemat opowiadający o konieczności jej faktycznego, a więc poetyckiego „zamieszkania” (zob. Amereida, t. 1, Valparaíso 1967). Istotne zmiany w świecie przeprowadzane za sprawą poezji miały dokonywać się w trakcie zbiorowych aktów poetyckich, tak zwanych phalènes. Rozumienie fundamentalnej roli poezji dla bycia człowieka w świecie, zaczerpnięte z twórczości Hölderlina i nowoczesnych francuskich poetów (między innymi Arthura Rimbauda, Comte de Lautréamonta), zrealizowało się w 1965 roku w travesía - przeprawie dziesięcioosobowej grupy poetów, architektów, rzeźbiarzy przez kontynent — oraz w ufundowaniu Miasta Otwartego (Ciudad Abierta, Chile 1970). Więcej o rozumieniu poezji, statusu języka oraz idei phalènes w: M. Barbaruk, Zabroniona funkcja języka. Przypadek Amereidy, „Konteksty. Polska Sztuka Ludowa” 2018, nr 1-2, s. 165-177; eadem, Poetic boundaries of open cities, „ПРА ve.html? year=2019\&issue=1\&article_id=7297 (dostęp: 29.09.2019).

32 Obserwacje miejskiego życia łączyły się z wykonywaniem charakterystycznych szkiców, których uczył Cruz i które wykonują także dzisiejsi studenci z Valparaíso; zob. np. A. Cruz Covarrubias, El Acto Arquitectónico, Valparaíso 2005.

Prace Kulturoznawcze 23, 2019, nr 2-3

(C) for this edition by CNS 
w Santiago poczuli się „osieroceni” (Puga) mimo wysiłków zespołu Larraína, by zdyskwalifikować tych, którzy odchodzili, przez nazywanie ich „szaleńcami”.

W 1952 roku grupa z Santiago ${ }^{33}$ ulokowała się w Viña del Mar koło Valparaíso, w miejscu nazywanym Cerro Castillo. Cruz uważał, że w pojedynkę nie można niczego zmienić i postanowił dzielić się swoją pensją ze współpracownikami. Podjęli oni decyzję, by zamieszkać w kilku domach na wzgórzu, co sprawiało, że nie musieli kończyć pracy wraz z opuszczeniem sali wykładowej. Inspirowali się pismami noblisty Françoisa Jacoba, który wyróżniał dwa typy wiedzy: „dzienną” i „nocną”. Francuski biolog był przekonany, że konwencjonalną, pojęciową naukę trzeba uzupełniać wiedzą, która rodzi się w tajemniczych, niejasnych obszarach ludzkiej psychiki.

Ann Pendleton-Jullian, opisując źródła inspiracji szkoły, przywołuje metaforę dnia i nocy - wiedzę „dzienną" łączy z Le Corbusierem (rola aktywnego doświadczenia w procesie kreacji), „nocną” z oddziaływaniem francuskiej poezji, zwłaszcza zaś surrealizmu (,nocna metodologia: pasywna recepcja nieświadomych myśli i — za sprawą tych myśli - połączenie z inną stroną myśli i egzystencji”34). Niemal natychmiast stało się jasne, że ich idea architektury jest radykalnie nowa, czego skutki komentuje Pendleton-Jullian:

\begin{abstract}
Siła zaangażowania przeszczepionej z Santiago grupy wywarła bardzo duży wpływ na orientację i pedagogikę szkoły architektonicznej. Niemal natychmiast trzeba było stworzyć w obrębie korpusu szkoły instytut architektury, odrębny od istniejącego wydziału i programów, aby zapewnić niezależność struktury dla prawdziwych i intensywnych badań. Instytut skoncentrował się na badaniach, które były laboratoriami dla architektów, poetów, malarzy, rzeźbiarzy i inżynierów. Odrzucili oni architekturę jako zawód z powodu kompromisów niezbędnych do formowania profesjonalistów, żaden profesor nie wytykał studentowi tego, czego sam nie zrobił. Stworzyło to bardzo silną moralność i autentyczną uniwersytecką kondycję rozumianą jako laboratorium myśli ${ }^{35}$.
\end{abstract}

Utworzony przez Cruza i Iommiego Instytut Architektury był autonomiczną jednostką działającą w obrębie Wydziału Architektury i Urbanizmu UCV. Architekci otrzymywali zlecenia za pośrednictwem UCV, co pozwalało im uniknąć pracy w profesjonalnych biurach architektonicznych (ten sposób pracy został zaczerpnięty ze szkoły w Ulm, które odwiedzili Iommi i Girola). Fabio Cruz opisuje, że w tamtym czasie na uniwersytecie panowały familiarne stosunki i porównuje go do „wielkiej parafii” ${ }^{36}$. Nawet jeśli grupa miała wpływ na postrzeganie studiów architektonicznych, to jej celem nie była reforma kierunku uniwersyteckiego ani zmiana społeczeństwa przez zaproponowanie nowej architektury

33 Architekci, którzy przyjechali z Cruzem i Iommim, to Arturo Baeza, Jaime Bellalta, Fabio Cruz, Miguel Eyquem, Francisco Mendez i José Vial. Później dołączył rzeźbiarz Claudio Girola.

${ }^{34}$ A.M. Pendleton-Jullian, op. cit., s. 55.

35 Ibidem, s. 16.

${ }^{36}$ F. Cruz, Reforma Universitaria UCV 1967, Viña del Mar 1999, https://www.josevial.cl/documex/reforma-universitaria-1967 (dostęp: 29.09.2019). 
i wzornictwa (różnili się więc od ,pozytywistycznej” Hochschule z Ulm). Misja szkoły z Valparaíso wypełniała się w badaniach podstawowych, nie zaś w laboratoryjnym wypracowywaniu rozwiązań.

Na sztandarze walki o zmiany w 1967 roku było napisane, że „To, co administracyjne, zdominowało to, co ściśle akademickie"37. Trzeba tu wyjaśnić, że problem ten był poważny, gdyż badań szkoły z Valparaíso nie można utożsamiać z wiedzą ,akademicką”, teoretyczną. Najdobitniejszym przykładem odmienności ich wizji jest idea poetyckiego fundowania architektury, czyli koncepcja phalènes ${ }^{38}$. Innym punktem kluczowym dla programu dydaktycznego szkoły były tak zwane obserwacje dokonywane w czasie wędrówek studentów po Valparaíso, które wymagały umiejętności „kontemplacji” (zatrzymania w miejscu w celu jego głębokiej analizy):

Kiedy rozpoczęła się nowa szkoła, w pierwszym semestrze I roku nauki Cruz zlecił zlokalizowanie konkretnego budynku w Valparaíso na podstawie fotografii. Każdy uczeń otrzymał inną fotografię. W trakcie semestru studenci rejestrowali swoje poszukiwania i spotkania z miastem. Pod koniec semestru niektórzy studenci wrócili, aby kontynuować naukę architektury, podczas gdy inni, dzięki swoim doświadczeniom, zostali poetami, muzykami, rzeźbiarzami, matematy$\mathrm{kami}^{39}$.

Zindywidualizowanie przebiegu procesu pedagogicznego i dydaktycznego oraz powstrzymywanie studentów, by „nie rysowali zbyt dobrze, gdy myślą za mało"40, wpływały na strukturę programu nauczania. Składał się on z dziesięciu semestrów. W każdym semestrze zlecano do wykonania zadania łączące studentów z różnych lat. Student oceniany był w odniesieniu do całej swojej aktywności podejmowanej w czasie studiów (zasada ciągłości). Studenci pracowali w mieście, a cała wspólnota szkoły zbierała się raz w tygodniu, by omówić efekty pra-

37 Ibidem.

38 Phalène, czyli akt poetycki, nigdy nie było formalnie ustrukturyzowane w programie nauczania szkoły. Poezja nie była rozumiana elitarnie, czego świadectwem było to, że studenci mieli wprowadzać ją w życie miasta. „Recytowali wiersze na ulicach, w autobusach, na wzgórzach, na plaży. Już nie jako widzowie, oni wchodzili w życie miasta jako uczestnicy i czynili z poezji jego uczestniczkę. Te recytacje, niemal zawsze dokonywane w grupach, rozwijały się w phalène. Wiele z oryginalnych phalènes było niezwykle prowokacyjnymi i radykalnymi interwencjami w życie miejskie Valparaíso, ponieważ istniała poetycka zasada, by »zmieniać z życia« [changing of life] a nie tylko »zmieniać życie« [changing life]. Nie zmieniać kursu życiowego ani nie zamieniać jednego życia na drugie, ale zmieniać to, co jest w samym sercu życia: jego istotę, cel i sposób życia” — A.M. Pendleton-Jullian, op. cit., s. 69. Podsumowując, należy stwierdzić, że między działaniami poetyckimi a architektonicznymi istniała pewna niezależność. Pełna realizacja możliwości phalènes, uczynienie z nich uprzywilejowanego sposobu poznania, mogła nastąpić dopiero po założeniu Miasta Otwartego koło Ritoque (1970). Przyznanie szkole na ten cel terenów było skutkiem żądań reformy z 1967 roku, ale dla krystalizacji postulatów manifestu dotyczących odnowy uniwersytetu znaczenie miało też zorganizowanie przez grupę w 1965 roku poetyckiej podróży (travesía).

39 Ibidem, s. 67.

40 Ibidem.

Prace Kulturoznawcze 23, 2019, nr 2-3

(C) for this edition by CNS 
cy. Badania były zgodne z ,poszerzonym” rozumieniem umysłu, włączającym na równych prawach analizę i intuicję.

Znamiennym przykładem niestandardowej metodologii Cruza może być przepisywanie „słowo po słow i e” dwóch książek Le Corbusiera i dokonywanie w nich pewnych korekt. Korelacja między tymi słowami a nauczaniem szkoły dotyczyła postawy twórczej, sposobu widzenia i działania, nie zaś formy architektonicznej, z której słyną obiekty budowane przez francuskiego modernistę. Dlatego też opisy ,plastycznych jakości, na których odciskały się »nowoczesne « obietnice technologii" ${ }^{41}$, były z tekstu usuwane. Cruz przepisywał też Entretien Avecles Étudiants des Écoles (1957), wykładnię pedagogicznych idei Le Corbusiera dotyczących pasji, procesu twórczego i fundamentalnych zadań architektury. Dla Cruza ważne było to, że Le Corbusier traktował poezję jako użyteczną i konieczną do życia nowoczesnych ludzi. Zachęcał do traktowania wiedzy jako podstawy budowania form życia.

Z kolei Iommi, wprawiając w osłupienie słuchaczy, mówił: „Uniwersytet musi być erotyczny, jeśli nie jest erotyczny, przestaje być uniwersytetem"42. Tłumaczył, że obecność Erosa w uniwersytecie polega na konieczności zakochiwania się w tworzonym dziele, namiętności i poświęceniu, jakiego wymaga nauka, radości płynącej z tego, że może stać się ona sposobem tworzenia swojego życia. Całkowite poświęcenie się architekturze ,jest pokrewne religijnemu oddaniu w skoncentrowaniu, sile i namiętności”"43, a to wymaga specyficznej intencji czynów.

Do opisywanej przeze mnie kulminacji kryzysu doszło dlatego, że badawczo-dydaktyczny program szkoły stał się niemożliwy do zrealizowania. To jednak nie wszystko. Na uniwersytecie doceniane były jedynie studia zawodowe i techniczne, a kolegialność i demokratyczność organów uniwersyteckich była fikcją. Biskupstwu (Vicario del Obispo) zarzucano centralizm i paternalizm. Gdy w 1963 roku kierowanie uniwersytetem powierzono rektorowi, osobie świeckiej, finansowanie nie było ani transparentne (środki na badania i stypendia były rozdzielane według uznania rektoratu), ani wystarczające (w części Instytutu Architektury nie było nawet światła ani wody). Kondycję UCV w 1967 roku Iommi nazywał ,antyuniw ers yte tem". Celem Manifestu 15 czerwca $1967^{44}$, który został przeczytany publicznie, przyjęty na Radzie Wydziału Architektury i Urbanizmu przez

41 Ibidem, s. 50.

42 Ibidem, s. 49.

43 Ibidem.

${ }^{44}$ Manifest z 15 czerwca 1967 roku dostępny jest online w postaci faksymile dokumentu (paginacja, 11 stron) wysłanego do biskupa Emilio Tagle Covarrubiasa (kuzyna Alberta Cruza) oraz w transkrypcji, która została opublikowana w 1971 roku w książce Fundamentos de la Escuela de Arquitectura. Tekst z 1971 roku różni się nieznacznie od dokumentu wysłanego do biskupa. Pozbawiona danych dotyczących władz UCV wersja dokumentu została także opublikowana w „El Mercurio" 16.06.1968, s. 52-53. Zob. G. Iommi Marini, Manifiesto del 15 de junio de 1967, [w:] idem, Fundamentos de la Escuela de Arquitectura, Santiago 1971, https://wiki.ead.pucv.cl/Manifiesto_del_15_de_Junio_1967 (dostęp: 27.09.2019) — wersja online bez paginacji. 
Zgromadzenie Studentów Wydziału i stał się symbolem buntu wobec władz UCV, było żądanie reorganizacji:

Z powodu niekwestionowanej tradycji uniwersytet był i jest w Ameryce depozytariuszem naszej odwagi. Dlatego tu i teraz, w Chile, w kraju, w którym chyba istniała i istnieje obywatelska tradycja i gdzie próbuje się amerykańskiej odnowy bez frustracji i przemocy, na tym już prawie starożytnym Universidad Católica de Valparaíso, którego istnienie za sprawą antyklerykalnych pokoleń świadczy o wolnym sposobie życia Chilijczyków, w tej szkole architektury, która od 15 lat stanowi prawdziwą i konkretną wspólnotę życia, utworzoną przez nauczycieli, profesorów i studentów walczących bez spokoju [sin paz] czy odpoczynku o ustanowienie na ziemiach amerykańskich miejsca, w którym wolność studiowania i otwartość na to, co własne, bez uprzedzeń, dogmatyzmu czy szowinizmu ${ }^{45}$, jest rzeczywistością, podnosimy naszą skargę i podejmujemy nieodwołalny krok, aby domagać się całej reorganizacji uniwersytetu we wszystkich jego aspek$\operatorname{tach}^{46}$.

Miała to być odnowa „amerykańska”, gdyż w dokumencie stwierdza się, że uniwersytety latynoamerykańskie nie wyzbyły się dotąd kolonialnego charakteru, importują obce pojęcia i ideologie, a uczeni pogrążają się w poczuciu niższości, brakuje im odwagi, by otworzyć się na rzeczywistość, zaakceptować historię i ryzyko ,przygody bycia tym, czym możemy być” ${ }^{47}$ :

Nie potrafiąc zrozumieć i odróżnić, czym są badania, status naukowy, nauczanie, zawód, relacje uniwersyteckie ze społeczeństwem, [uniwersytet - M.B.] żył i wciąż żyje zafascynowany a zatem bez konsystencji - dużymi uniwersytetami na innych kontynentach, oddany jedynie transpozycjom, które z braku klarowności i podstaw, były — a w większości przypadków zwykłymi snami i ciągłymi improwizacjami. Dobrym tego dowodem są nieliczne przypadki wytrwałości w określonym zadaniu ${ }^{48}$.

Reformatorzy żądali uznania, że uniwersytet stanowi wspólnota akademicka profesorów i studentów, domagali się podniesienia prestiżu instytutów naukowych, poskromienia biznesowego podejścia do nauki, czynienia z wiary użytku propagandowego (public relations wiary), zapewnienia autonomii i apolityczności. Podkreślali, że celem buntu wobec władz kościelnych nie jest atak na katolickość, gdyż wiara jest dla nich fundamentem aksjologicznym otwartości, sprawiedliwości, ubóstwa: „w obecnych czasach hojny, męski, wzniosły horyzont proponują tylko szczere ruchy rewolucyjne lub autentyczna wiara religijna"49. Szkoła wpisywała się w nurt „odnowy katolickiej”, który zdaniem Mario Góngory cechował się skłonnością do poetyckiej wrażliwości i unikał partyjnej poli-

45, ,[H]acialopropio, sin prejuicios, dogmatismo ni chauvinismo” zostało dodane do wersji manifestu z 1971 roku - G. Iommi Marini, op. cit.

${ }^{46}$ Faksymile dokumentu manifestu, s. 1, https://www.ead.pucv.cl/1971/manifiesto-del-15-de-junio-de-1967/ (dostęp: 27.09.2019).

47 Ibidem. „Nasze uniwersytety są kapryśne i żebrzące, jeśli chodzi o rodzaje, pieniądze, metody, orientacje, badania i kulturę, a poprzez to są instytucjami niezdolnymi do dostosowania nas do tego, co jest lub może być naszą, Amerykanów, rzeczywistością, jeśli ją mamy" - ibidem, s. 3 .

48 Ibidem, s. 2.

49 Ibidem. 
tyki. Generacji tej (a należał do niej też zasłużony dla Chile prezydent Eduardo Frei oraz wybitni artyści awangardowi Roberto Matta i Juan Borchers) bliskie były idee niemieckiego romantyzmu, historycyzmu mieszającego idee Herdera, Hegla, Spenglera, Heideggera, Rilkego i Huidobro, a także krytyka kapitalizmu (konsumpcjonizmu), materializmu burżuazji, technokracji ${ }^{50}$. Za Góngorą można powiedzieć, że misją uniwersytetu w Chile było wytworzenie nowych, prawdziwych elit, które mogłyby obronić społeczeństwo przed światowym kryzysem lat osiemdziesiątych, „demokracją mas” i zapewnić Ameryce Łacińskiej polityczną i społeczno-kulturową stabilność. Czy powinny być to elity katolickie? Góngora mówi o starannie wybranych, wolnych ludziach uniwersytetu. Cytuje jednak zdanie, które Heidegger wypowiedział w jednym z wywiadów w 1982 roku: „Tylko Bóg może nas uratować!". Wydaje się, że Góngora ratunek dla kultury i społeczeństwa widział w małych wspólnotach, „sektach »katechumenów«"51. Alfredo Jocelyn-Holt, analizując poglądy Góngory na misję uniwersytetu i jego poczucie pokrewieństwa ze szkołą z Valparaíso, zastanawia się, czy w ten sposób (to jest jako o grupie quasi-religijnej) trzeba myśleć o uczonych z Miasta Otwartego, które poeta i architekt Ignacio Balcells nazwał zresztą „Arką Babel”.

W manifeście artykułowane jest też wyraźnie żądanie uznania użyteczności badań szkoły. Choć trzeba odróżniać poszukiwanie prawdy (,swobodna i bezinteresowna k on te m pl a c j a [wyr. - G.I.M.] tego, co może stanowić naszą własną rzeczywistość" ${ }^{52}$ ) od działań politycznych, wspierania społeczeństwa i kultury, Iommi i Cruz nie chcą, by Instytut Architektury traktowano jako „wieżę z kości słoniowej":

Mimo że od zawsze odpowiadaliśmy na potrzeby kraju, wychodząc z rzeczywistego stanu badań (budynki kościołów na południu, badania interdyscyplinarne (sic!) w miejscowości Rocuant, studia dla biskupów i diecezji po trzęsieniu ziemi w 1960 roku; odbudowa miasta Quillota po trzęsieniu ziemi w 1965 roku; analizy 46 przypadków dla Operación Emergencia, za które odpowiedzialne było Kwatermistrzostwo Valparaíso, akty [poetyckie - M.B.] z pracownikami morza - od Horcón do Caleta El Membrillo — uczestnictwo w nich naszych studentów podczas zajęć letnich etc.), władze uniwersytetu nie wahały się atakować szkoły, wskazując na nią jako na „wieżę z kości słoniowej” (sic!), zamkniętą, odporną na dialog albo utopijną, próbując pozbawić ją prestiżu wobec innych wydziałów, szkół i jej własnych studentów ${ }^{53}$.

${ }^{50}$ A. Jocelyn-Holt, La complejidad de unaobra y su historia pendiente, [w:] Ha-Lugar de un Encuentro. En torno al libro "El Acto Arquitectónico", de Alberto Cruz C., Valparaíso 2012, s. 23.

51 Ibidem, s. 26.

52 G. Iommi Marini, op. cit., s. 3.

53 Ibidem, s. 6. Pendleton-Jullian podaje istotny dla zrozumienia krytycznego potencjału urbanizmu szkoły przykład projektu osadnictwa dla 500 tysięcy robotników w Archupallas. Znajduje się ono na porośniętym drzewami wzgórzu 7 kilometrów na północ od Valparaíso, skąd rozpościera się widok na Pacyfik i Viña del Mar. „Projekt, który składa się z dwóch części, założenia teoretycznego i praktycznej propozycji, zaczął się od odrzucenia konwencjonalnej metodologii planowania, w tym wypadku aplikacji modernistycznego cité jardin, jak postulowali deweloperzy projektu" - A.M. Pendleton-Jullian, op. cit., s. 115. Więcej o tym niezrealizowanym projekcie zob. ibidem, s. 115-125. Są jednak przykłady świadczące o pragmatycznym podejściu Cruza i Iommiego. Rok po strajku Instytut 
Zgodnie z sięgającą starożytności ideą uniwersytetu jego istotą jest bezinteresowne poszukiwanie i krzewienie prawdy naukowej. To ona jest wartością najwyższą, niemożliwą jednak do osiągnięcia bez wolności („Prawda i wolność tworzą tu nierozdzielną parę i warunkują się nawzajem"54). W latach sześćdziesiątych w Chile istniało wiele heteronomii prawdy: zwierzchnictwo kościelne, profesjonalizacja i specjalizacja wiedzy, ekonomia, polityka. Brak autonomii nauki był dla szkoły z Valparaíso problemem ważnym. Rezultatem ich troski o niezależność własnych badań jest zarzut apolityczności „grupy Amereidy” w czasie dyktatury Pinocheta (1973-1990), sformułowany najpierw w płomiennym przemówieniu historyka Alfredo Jocelyn-Holta, podczas świętowania książki Acto arquitectónico Alberto Cruza, potem w docenionym eseju Any Marii Léon, w którym porównała ona wspólnotę pracującą i żyjącą w Mieście Otwartym do dobrowolnych więźniów (w latach 1974-1975 w pobliżu funkcjonował obóz koncentracyjny dla więźniów politycznych, w tym lewicowych aktorów teatrów uniwersyteckich; zdaniem Léon byli oni bardziej wolni niż profesorowie uniwersyteccy ${ }^{55}$ ).

Po zamachu stanu w Chile wiele uniwersytetów przeszło kontrreformę, a teatry uniwersyteckie zamknięto (szef Teatru Aleph, Oscar Castro, przebywał w obozie w Ritoque) albo wymieniono ich składy. W Chile przez siedemnaście lat uczelnie nie miały autonomii (zlikwidowano senat), a mimo to w tym czasie funkcjonowało Miasto Otwarte - główne miejsce badań i praktyk architektonicznych szkoły z Valparaíso po 1970 roku. Herbert Schnädelbach nie ma wątpliwości, że uniwersytet niemiecki skapitulował w pełnieniu swej misji w 1933 roku, kiedy zaczęto zmieniać Uniwersytet Humboldta w Uniwersytet Narodowosocjalistyczny. Czy apolityczności twórców Amereidy nie należy porównywać z prywatyzacją wiedzy w niemieckim mieszczańskim społeczeństwie? „Polityczna abstynencja” ${ }^{56}$ jako wzór zachowania ludzi wykształconych, uczynienie z kształcenia sprawy wewnętrznej, było ważnym powodem, dla którego uniwersytet nie przeciwdzia-

Architektury podjął współpracę z prywatnym chilijskim wydawnictwem ZIG-ZAG, którego dyrektorem artystycznym był Włoch, Vittorio Di Girolamo. Jego zdaniem był to znak modernizacji uniwersytetu, który nie był wtedy możliwy w Europie. Podpisanie porozumienia opisywane było jako „rewolucyjna droga na polu narodowej edukacji”, gdyż przed uzyskaniem tytułu student miał możliwość łączenia teorii i praktyki, to jest pracy jako projektant grafiki. Specjalizacja trwała dwa lata, zatem nawet nie kończąc całych studiów (czyli nie uzyskując tytułu architekta), miało się zawód projektanta grafiki. Trzeba zaznaczyć, że publikacje instytutu to obiekty artystyczne, w których forma jest nieoddzielna od treści (wiele z nich to książki poetyckie czy wykłady Iommiego).

${ }^{54}$ W. Stróżewski, op. cit., s. 13.

55 Jeśli mowa o apolityczności szkoły z Valparaíso, trzeba zauważyć kolejny paradoks. To reformy uniwersyteckie z 1967 roku doprowadziły do reorganizacji teatrów uniwersyteckich w interdyscyplinarne struktury akademickie. Teatr mógł stać się narzędziem zmiany społecznej, mimo że był powiązany z uniwersytetem katolickim, czyli wyższą klasą średnią. Zob. A.M. Léon, Prisoneros del Ritoque. La Ciudad Abierta y el centro de detención, „ARQ” 2016, nr 92, https://scielo.conicyt.cl/scielo.php?script=sci_artte xt\&pid=S0717-69962016000100009 (dostęp: 27.09.2019).

${ }^{56}$ H. Schnädelbach, op. cit., s. 55. 
łał narodowemu socjalizmowi i „zawiódł"57. Mieszczaństwo zapragnęło mieć wodza, bo nauka nie dawała pewności, a oni nie stworzyli nowego duchowego światopoglądu.

O takiej aksjologicznej próżni i braku poczucia odpowiedzialności za kraj, kontynent amerykański, jego mieszkańców — jak dowodziłam wcześniej — nie może być mowy w wypadku szkoły z Valparaíso. Nie jest ona też najlepszą ilustracją tezy mówiącej, że nawet jeśli apolityczność przynosiłaby złe skutki, nie wolno uniwersytetowi od niej odstąpić, by nie sprzeniewierzyć się swojej istocie ${ }^{58}$. Profesorowie Amereidy jako wspólnota universitas po 1973 roku działali zgodnie z własnym programem (,filozofią"), a zaangażowanie się w bieżącą politykę byłoby z nich rezygnacją. Ich praktyka nie była jednak programowo apolityczna, nie znam też przypadku, w którym doszłoby do sytuacji wyboru między „misją uniwersytetu” a polityką (profesorowie nie wiedzieli o obozie koncentracyjnym, a program dekolonizacji Ameryki można uznać za polityczny ${ }^{59}$ ).

Nie potrafię jednoznacznie określić swojego stanowiska w sprawie „milczenia profesorów" w czasie dyktatury Pinocheta. Zarzuty Jocelyn-Holta i Léon, wsparte są efektownymi obrazami i figurami, które utrudniają refleksję (historyk przypomina, że 5 kilometrów od szkoły Bauhausu w Weimarze był obóz w Buchenwaldzie, a obóz w Ritoque dzieliło od Miasta Otwartego 9 kilometrów, podczas gdy przez teren Miasta przejeżdżał pociąg wiozący więźniów). Wymagałoby to najpierw rozstrzygnięcia problemu, kiedy można powiedzieć, że uniwersytet abdykował ze swojej misji. Z uwagi na brak możliwości ahistorycznego i nieuwzględniającego kulturowej zmienności stwierdzenia, co stanowi misję uniwersytetu, trudno mówić o rezygnacji z niej (klęsce, kapitulacji, zawodzie). Samo wskazanie na kluczowe wartości tworzące ideał universitas nie wydaje się wystarczające. Jak wykazywał Stróżewski, uniwersytet jest instytucją „dziwną”, paradoksalną i dlatego też jego misja nie jest łatwa do eks-

${ }^{57}$ L. Curtius stwierdził: „Niemieckie uniwersytety miały wspaniałe osiągnięcia w zakresie kształcenia uczonych, ale zawiodły w dziele duchowego wychowania narodu, które było ich zadaniem" - cyt. za: H. Schnädelbach, op. cit., s. 58-59.

58 Taki pogląd głosił Kazimierz Twardowski podczas wykładu na Uniwersytecie Poznańskim w 1933 (sic!) roku: ,postulat radykalnej, całkowitej apolityczności uniwersytetu i wynikające z niego konsekwencje praktyczne, nie są czymś doraźnym czy akcydentalnym, lecz znajdują swe zakorzenienie w idei uniwersytetu, potwierdzonej doświadczeniem jej historycznych realizacji, zarówno tych udanych, szczęśliwych, jak i tych, które się nie sprawdziły, gdyż po prostu idei tej nie były wierne" - cyt. za: W. Stróżewski, op. cit., s. 17.

${ }^{59}$ Warto dodać, że pierwszą travesía, której trasa prowadziła z Punta Arenas do nowej, poetyckiej, stolicy kontynentu Santa Cruz de la Sierra, przerwali boliwijscy wojskowi pod pretekstem grasującej w terenie partyzantki Che Guevary (grupę szpiegowano i tylko dzięki osobistym kontaktom Iommiego udało się uniknąć poważnych kłopotów); zob. dziennik wyprawy dołączony do: Amereida, t. 2, Valparaíso 1986, s. 199-202. 
plikacji ${ }^{60}$. Jedną z przyczyn jest to, że sposoby realizacji wartości stanowiących o jego powołaniu wydają się je podważać, a walka o zachowanie istoty uniwersytetu wymaga nierzadko czynów z nią niezgodnych (na przykład strajku czy „inkwizytorskiego” gestu palenia książek).

\section{$* * *$}

Strajk na UCV w 1967 roku trwał pięćdziesiąt dni, „ostatecznie reforma została zaakceptowana"61. Uniwersytet, o który walczyli twórcy Amereidy, jest przedmiotem stawiającym wyzwanie badaczom. Gdy próbuję go charakteryzować, na myśl przychodzi mi książeczka Jacques'a Derridy Uniwersytet bezwarunkowy ${ }^{62}$. Derrida przyjaźnił się z Michelem Deguy, uczestnikiem pierwszej travesía, która miała na celu poetyckie zamieszkanie Ameryki, słyszał zatem od niego o Los Locos de Valparaiso ${ }^{63}$ i rezultatach ich działalności. Pisząc swoją książkę, francuski filozof nie myślał jednak o stworzonym przez Cruza i Iommiego utopijnym, alternatywnym Mieście Otwartym ${ }^{64}$. Jak zapewniał mnie Deguy, Derrida troszczył się wyłącznie o lokalną, francuską, instytucję, której był współzałożycielem (chodzi o powołane w 1983 roku Collège international de philosophie, CIPH). Być może taki sposób kontynuowania refleksji o misji uniwersytetu - dokonywany z jego obrzeży, od wewnątrz, z pozycji aktywnego, sprawczego twórcy — okazuje się dla tej instytucji prawdziwie ożywczy i może mieć wymiar uniwersalny (światowy).

60 „Zaiste, dziwnym tworem jest uniwersytet. W imię wolności poszukiwania i krzewienia prawdy rezygnuje z praw, jakie przysługują innym. Odizolowany w szczególny sposób od społeczeństwa, dla niego przecież, dla jego dobra pracuje. Oderwany od polityki — wykuwa teoretyczne argumenty, które w polityce będą mogły być wykorzystane. Zdany na utrzymanie przez państwo, równocześnie pragnie zachować wobec niego całkowitą autonomię. Pozaczasowy w swej idei, odległy od teraźniejszości w swych historycznych początkach równocześnie stara się za wszelką cenę o dotrzymanie kroku współczesności i utrzymanie kontaktu z aktualnym stanem nauki światowej. Ale taki powinien właśnie być i pozostać, jeśli nie ma zatracić swej tożsamości, ma natomiast w sposób właściwy spełniać swe powołanie" - W. Stróżewski, op. cit., s. 22.

${ }^{61}$ F. Cruz, op. cit. Cruz dobrze relacjonuje przebieg strajku, polityczne rozgrywki różnych grup oraz konsekwencje reformy, której bezpośrednim rezultatem było ustalenie, kiedy i w jaki sposób odejdzie rektor.

62 Więcej o Mieście Otwartym jako uniwersytecie bezwarunkowym zob. M. Barbaruk, Opór naturalny. Amereida jako nieheroiczna wyprawa i uniwersytet bezwarunkowy, „Praktyka Teoretyczna" 2019, nr 2 (32), s. 109-128.

${ }^{63}$ V. di Girolamo, Los Locos de Valparaíso, 18.10.1972, s. 49, cyt. za: A.M. Pendleton-Jullian, op. cit., s. 2.

${ }^{64} \mathrm{Na}$ moje pytanie, czy Derrida, pisząc o idei uniwersytetu, mógł mieć na myśli Miasto Otwarte, Michel Deguy zaprzeczył — zapis rozmowy M. Barbaruk z M. Deguyem, która odbyła się 11 września 2019 roku w Paryżu (w posiadaniu autorki). 


\title{
University mission: The fight for reform at the Catholic University in Chile
}

\author{
Abstract
}

The author asks about the mission of the university understood as an axiologically defined way of life. She follows the history of the university reform in Chile in the 20th century, its two key moments from the point of view of university reflection: the strike in 1949 and in 1967. She notes that the strike phenomenon, although contrary to the idea of the university, is a tool for the disclosure of the university community. Both strikes were organized by architecture students at private Catholic universities (in Santiago and Valparaíso, respectively), hence the demands for total reorganization, research autonomy, modernization and democratization can be regarded as radical. The author describes the research and teaching practice of the so-called School of Valparaíso, which can be considered the most important source and largest beneficiary (having been granted the Open City area) of the university reform in Chile. The ideas of architect Alberto Cruz Covarrubias and poet Godofredo Iommi Marini are also a good case for analyzing the problem of university autonomy (the issue of apoliticality) and questions about when the university fails in its mission.

Keywords: university, values, reform, strike, Catholic University of Valparaíso (UCV), university reform of 1967, "School of Valparaíso," Alberto Cruz Covarrubias, Godofredo Iommi Marini

\section{Bibliografia}

Amereida, t. 1, Valparaíso 1967.

Amereida, t. 2, Valparaíso 1986.

Barbaruk M., Opór naturalny. Amereida jako nieheroiczna wyprawa i uniwersytet bezwarunkowy, „Praktyka Teoretyczna” 2019, nr 2 (32).

Barbaruk M., Poetic boundaries of open cities, „ПРАЕHMA. Journal of Visual Semiotics” 2019, $\mathrm{nr}$ 1, https://praxema.tspu.edu.ru/en/archive.html?year=2019\&issue=1\&article_id=7297 (dostęp: 27.09.2019).

Barbaruk M., Zabroniona funkcja języka. Przypadek Amereidy, „Konteksty. Polska Sztuka Ludowa”, 2018, nr 1-2.

Cruz F., Reforma Universitaria UCV 1967, Viña del Mar 1999, https://www.josevial.cl/documex/ reforma-universitaria-1967 (dostęp: 27.09.2019).

Cruz Covarrubias A., El Acto Arquitectónico, Valparaíso 2005.

Derrida J., Uniwersytet bezwarunkowy, przeł. K.M. Jaksender, Kraków 2015.

Di Girolamo V., ZIG ZAG y UCV crean una nuevacarrera, https://www.josevial.cl/escuela-de-diseno/crean-una-nueva-escuela (dostęp: 27.09.2019).

Iommi Marini G., Manifiesto del 15 de junio de 1967, [w:] idem, Fundamentos de la Escuela de Arquitectura, Santiago 1971, https://wiki.ead.pucv.cl/Manifiesto_del_15_de_Junio_1967 (dostęp: 27.09.2019).

Jocelyn-Holt A., La complejidad de una obra y suhistoriapendiente, [w:] Ha-Lugar de un Encuentro. En torno al libro "El Acto Arquitectónico", de Alberto Cruz C., Valparaíso 2012.

Kołakowski L., Po co uniwersytet?, „Gazeta Wyborcza” 14.03.1994.

Prace Kulturoznawcze 23, 2019, nr 2-3

(C) for this edition by CNS 
León A.M., Prisoneros de Ritoque. La Ciudad Abierta y el centro de detención, „ARQ” 2016, nr 92,https://scielo.conicyt.cl/scielo.php?script=sci_arttext\&pid=S0717-69962016000100009 (dostęp: 27.09.2019).

Majewski T., Nowa idea uniwersytetu, „Znak” 2018, nr 10 (761). Uniwersytet to my.

Ortega y Gasset J., Misja uniwersytetu, „Pressje”, przeł. J. Rzegocka, A. Rzegocki, https://pressje. pl/media/pressje_shop/article/article_17_issue12.pdf (dostęp: 27.09.2019).

Pendleton-Jullian A.M., The Road That is Not a Road and the Open City, Ritoque, Chile, Cambridge, MA 1996.

Pérez Oyarzun F., Arquitecturaen el Chile del Siglo XX, t. 2. Modernización y vanguardia 19301950, Santiago de Chile 2016.

Puga Concha M., La Quema del Vignola, nagranie z 25 listopada 2014 roku, zrealizowane na Wydziale Architektury Uniwersytetu Katolickiego w Santiago de Chile, https://vimeo. com/113156995 (dostęp: 31.08.2019).

Reyes Gil J., La Reforma de la Universidad Católica de Valparaíso de 1967: Una Reoriginación Poética, http://www.ead.pucv.cl/2010/una-reoriginacion-poetica-la-reforma-de-1967 (dostęp: 27.09.2019).

Rodríguez L., La Vanguardia en Chile. Reforma de 1949 en La P.U. Católica, „CA” 1992, nr 69.

Schnädelbach H., Filozofia w Niemczech 1831-1933, przeł. K. Krzemieniowa, Warszawa 1992.

Staruszkiewicz A., Komentarz do wyktadu Profesora Meissnera, „Foton” 2010, nr 110, http://www. foton.if.uj.edu.pl/documents/12579485/846c3dab-da85-413a-bc2a-3720cd6a426b (dostęp: 27.09.2019).

Stróżewski W., W kręgu wartości, Kraków 1991.

Twardowski K., O dostojeństwie Uniwersytetu, Poznań 1933.

Prace Kulturoznawcze 23, 2019, nr 2-3

(C) for this edition by CNS 